\title{
Governance practices in private management colleges in West Bengal: a perceptual undertone of faculty members
}

\author{
Prasanta Guha ${ }^{1,2^{*}}$ and J. K. Pattanayak ${ }^{\mathbf{1}}$ \\ ${ }^{I}$ Indian Institute of Technology (Indian School of Mines), Dhanbad, India. \\ ${ }^{2}$ Future Business School, Kolkata, India.
}

\begin{abstract}
An academic institution ensures its sustainability with good governance. The higher education sector is facing many challenges not only in India but globally as well, and practicing good governance is one of them. Many kinds of literature have coined governance practices in education institutes to date. This paper deals with the perception of faculty members towards governance practices in different private management colleges in West Bengal. The study has used descriptive statistics, factor analysis and regression statistics to analyse the data. The study has found a perceptual gap of the faculty members towards an ideal state of governance and practicing governance. The results show that the private management colleges in West Bengal have been suffering from not exercising good governance in the area of system, structure, management style, culture, accountability and compliance, and communication.
\end{abstract}

Keywords: Governance, higher education institutes, ideal governance, faculty perception, private management colleges.

\section{INTRODUCTION}

Since independence, higher education institutes are growing in number. As per the information provided by the Ministry of Human Resource Development of India, the number of universities has expanded by 34 times during the period of 1950-2014. The number of colleges has also increased by 74 times during 1950-2013 (India, Ministry of Human Resource Development, 2016). Management education in India started in the 1960s. As per All India Council for Technical Education (AICTE) approved institution list of 2015-16, there are
52 institutions which are running MBA programmes on full-time or part-time basis under the affiliation of eight universities or other bodies, or acting as autonomous bodies in West Bengal (India, All India Council for Technical Education, 2017). As per AICTE norms, university affiliation is mandatory for offering a Master's degree programme. However, there are institutions offering postgraduate diploma courses independently. Out of all the colleges offering management programs, a significant number, especially private management colleges, are affiliated under Maulana Abul Kalam Azad University of Technology (India, Maulana Abul Kalam Azad University of Technology, 2017). Recommendation of the National Knowledge Commission (2009) and the Yash Pal Committee (2009) reports are more pertinent in this context and suggest more educational opportunities can be created by stimulating private service providers. The present study rests on a sample drawn from a population of 50 private colleges offering MBA programmes under the affiliation of the Maulana Abul Kalam Azad University of Technology in West Bengal.

\section{LITERATURE REVIEW}

In this section, a detailed discussion on literature pertaining to governance practices in higher education institutes is presented. This section reviews the issues viz. higher education challenges, governance in higher education institutes and factors influencing good governance practices.

"Corresponding author (guhapra@gmail.com; (iD https://orcid.org/0000-0003-3815-6783) 


\section{Higher education challenges}

Researchers have addressed different issues and challenges in higher education to date. Out of different issues, low gross enrolment ratio, quality education, research and development issues, faculty shortage etc. are identified as critical challenges in higher education institutes (Modi, 2014). Chahal (2015) expressed a few challenges of higher education in India viz. traditional methods of teaching, lack of financing, quality teaching, privatisation, quota system etc. Srivastava (2006) identified 'over centralisation'-limiting institutional autonomy, 'variable quality', weak knowledge creation due to low interaction with the social elements along with the lack of qualified teachers and lack of funding in Indian higher education sector. Jesiah (2010) found a deficiency and a gross lacuna in the sphere of internationalisation of higher education institutions. The study brought to focus that measures viz.: acquisition of adequate funding, proper resource utilisation, appropriate policy and compliance control strategy, bridging the departure between the mediocre and the premier higher education institutions and minimising the gap between the Indian and foreign universities, all may go a long way to enable the Indian higher education sector to be more compatible and congruent with the global environment so to say.

Similar type of challenge is also felt in other developing countries where enabling lifelong education with or without a degree, joining of mass population in higher education, enhancing research capability, growing universities as a center of excellence are in conflict (Schwartzman, 2001). Developing countries like Pakistan are facing a challenge in the higher education sector in relation to governance, academic standard, staff quality, library resources, sound laboratory and research facilities etc., whereas universities in Iraq are facing the challenges of autonomy, i.e. freedom of polity, religion and ethnicity. Similarly, Turkey also lags behind international standards along with the inequality in education and access by gender, location and socioeconomic group (Rasian, 2009). Meyer et al. (2011) found another challenge in the South African higher education scenario; a considerable gap exists between global university standards and the local universities. Abolition of communism and the establishment of democracy led to invite globalisation in to the higher education sector in South Africa. The intensification of globalisation made the mindset change of the local university to prepare students for the global market instead of local. de Lourdes Machado-Taylor (2011) finds that, presently, higher education is running under a complex environment. It needs visionary leadership to adopt the change in the environment. The study also suggested that Complex Adoptive System (CAS) is a way of explaining and envisioning the institution with the environment.

As in the case of higher education, several challenges are also prominent in management education. Issues of non-availability of qualified faculty members with or without $\mathrm{PhD}$, a more soft-skill-based curriculum, lack of funds, deficiency in appropriate branding, need of alumni networking, foreign exchange program etc. are visible today (Hawawini, 2005).

\section{Governance in higher education institutes}

Governance decides who holds power, who takes decisions and how other stakeholders make their voices heard and who is accountable. Governance is the,

"exercise of economic, political and administrative authority to manage a country's affairs at all levels. It comprises mechanisms, processes and institutions, through which citizens and groups articulate their interests, exercise their legal rights, meet their obligations and mediate their differences"(Umar, 2016).

Researchers have indicated that good governance can ensure better performance of the organisation (Dayanandan, 2013; Duncan, 2003). Performance of academic delivery in higher education is linked with quality learning. Quality learning also depends on methods of learning applied and the effectiveness of the method of learning again depends on the socio-economic background of the students, student motivation and study skills. The same method of study may not be effective for all and hence, a customised approach can be more effective for students' performance (Mutsotso \& Abegna, 2010). Achieving total quality in higher education institutions, monitoring and self-assessment will work as a dimension of governance practices. Quality function deployment is an integral approach to address tangible and intangible resources which will act as a means of academic reforms (Singh et al., 2008).

Managing knowledge plays a pivotal role in higher education. Explicit and tacit knowledge in convergence with e-business can create a platform of effective decision-making and ensure better academic and administrative services to the stakeholders. It may further be an enabler for developing the necessary curriculum and research activities and moreover reduce costs of academic monitoring and administration (Kidwell et al., 2000). At present, an appropriate convergence of economy, society and polity demands the sustainability of an institution in the society (Aloj, 2007). Rapid growth in tertiary education, emergence of different types of institutions, introduction of different modes of 
delivery-such as e-learning, heterogeneous student inclusion in higher education in terms of socioeconomic background, ethnicity, growing number of female students, internationalisation of higher education and active involvement of research and innovation in higher education makes the need of good governance in the higher education sector more prominent today.

Good governance influences educational outcomes positively and it also helps in formulating different education policies. Greater accountability, political stability, government effectiveness, regulatory quality, rule of law and controlling corruption help to increase educational efficiency (Zaman, 2015). Effective governance provides the platform to stakeholders of an education institute to share a common vision and purposes (Franzoni \& Gennari, 2013). Brusoni et al. (2014) in a report on 'Concept of excellence in higher education' has focused on the areas of excellence in management practices, teaching, research and student performance. The notion of accreditation has become an added element to acquire; a feather in the cap of excellence of a Business School today (Sahay \& Thakur, 2007).

\section{Factors influencing good governance practices}

Practicing governance is involved in the academic chain starting with student admission to placing a student. In this process, ethical leadership plays a pivotal role to create an ambiance of good governance in the system (Othman \& Rahman, 2014). Authority and role clarity are instrumental to contribute to better governance practices. Besides, the autonomy of the institution also adds value to good governance (Loku Waduge, 2011). In an institution, a perceived gap between a good idea and its implementation has become high-flying. Here, the elements of governance for boosting up institutional performance acts as a propeller through accountability, standard incentive and with effective information (Lewis \& Pettersson, 2009). Salvioni \& Cassano (2017) suggested a standard accountability model for effective performance management in higher education institutes. Good governance is explained in a report by USAID (2003) as it “... requires a standard of accountability and transparency for the delivery of public services, such as basic education". A similar view is expressed in the drafted Policy Paper (April 1999) of the African Development Bank; exercising good governance in the organisation, elements like accountability and transparency are essential (International Fund for Agricultural Development, 2017). Trust is one aspect which promotes good culture in the organisation. It creates a good environment ensuring sound teamwork to achieve better educational performance (Migliore, 2012).
Besides trust, equity needs to be mentioned. An article of United Nations has mentioned that equity is explained when "a society's well being depends on ensuring that all its members feel that they have a stake in it and do not feel excluded from the mainstream of society" (United Nations Economic and Social Commission for the Asia and Pacific, 2009). Nestor \& Jesover (2000) have also expressed that the existence of equity in the system strengthens the governance practices and enables to achieve quality. Organisational culture is also influenced by the discipline in the institution. There is a commonness in thinking of the stakeholders like students, teachers and administrators, on that discipline, which is inevitable in managing an institution (Asare \& Adzrolo, 2013). "Discipline is a necessary condition for university work and no university can afford to work in an atmosphere of indiscipline" (Tettey-Enyo, 1995). Teamwork has always been fruitful in the execution of the planning for good governance. A team player is preferred than a long range player in higher education institutes, where individualism along with caring own status quo mislead them to achieve an organisational goal. It results in hampering academic or administrative decision-making. In the participative decision-making process, the expertise of different stakeholders viz. staff or students, can be optimised and hence, implementation becomes fruitful (Leach, 2008). Srivastava (2009) also expressed that a sound governance system is backed by participative decisionmaking. Besides, decision-making is interlinked with the generation of effective information. In the present era of Information Technology (IT), use of IT acts as a catalyst in creating effective information and escalating transparency and accountability among the stakeholders with an empowerment for taking appropriate decisions (Yallaprgada \& Vitukuru, 2012; Sapru \& Sapru, 2014). "The next level, i.e. communicating information, is also a challenge in the organisation where communication is indispensable to good governance" (Okwechime, 2015). It also supports that accessibility to the right information is a pathway to good governance (Chitumbo \& Kakana, 2011). Good governance practices demand compliance with the existing rules and incorporate checking tools in the process (Alhaj \& Yusoff, 2012). Malesela (2016) also emphasises the role of monitoring and evaluation to ensure good governance in higher education institutes. The compliance mechanism opens the road of measuring efficiency and effectiveness of the stakeholders and these hold a strong impact in attaining good governance practices (Srivastava, 2009).

In promoting good governance practices, managing satisfaction is an add-on to it. Martirosyan et al. (2014) derived a positive relationship between student satisfaction and their performance. Again, student satisfaction is linked with the location of the institution, 
academic aspect, image, infrastructure, cost and personnel of the organisation. A quality teacher can leave a mark on the mind of the students, yield satisfaction and engender a good academic environment in the institution (Ravindran \& Kalpana, 2012). Many experts are also of the opinion that students' quality influences the institution's governance practices. One challenge of higher education, which is relevant in the context of academic ambiance, is to develop an adequate set of research and development activities. In India, researchers are small in number. Faculty members are required to be motivated by research and good governance focuses on the platform to create such an opportunity of research in higher education and to frame a required policy to motivate researchers (Thanuskodi, 2011).

The discussion of challenges of higher education followed by governance in higher education has narrowed down by outlining few elements such as authority, accountability, transparency, trust, discipline, participative decision-making, effective communication and information accessibility, use of information technology in governance practices, compliance, stakeholders satisfaction and research activity as supportive elements for practicing governance in higher education institutes.

\section{RESEARCH METHODOLOGY}

Continuing with the flavor of the discussion, the objectives of the study can be framed as:

1. To study the gap between the ideal state of governance and current governance practices in private management colleges in West Bengal.

2. To study the factors influencing governance practices in private management colleges.

3. To frame a model of measuring practicing governance in the private management colleges.

In line with the objectives and considering the discussed elements of governance practices viz. authority, accountability, discipline, transparency etc., a structured questionnaire was designed. Data were collected by a survey through online and offline means, using the designed questionnaire. Total of 127 complete responses were collected from the faculty of different management colleges in West Bengal, affiliated to Maulana Abul Kalam Azad University of Technology. Out of 135 respondents who were communicated online, only 29 responded. Out of this 29, 24 responses were complete and usable for the study. The offline survey resulted in 103 complete responses. The scale was designed in such a way that the responses could be derived with regard to both an ideal governance situation as well as the situation in practice. A continuous rating scale of 0 to 10 was used where 0 denotes strong disagreement with the statements and 10 denotes strong agreement with the statements.

There were 30 statements focusing on ideal state and 25 statements with an eye on the practicing state of governance. Faculties rated the statements as per scale ranging from 0 to 10 and each questionnaire provided a rating of the ideal state and practicing state governance in their organisation. The study further calculated the average score of the statements on the ideal state and practicing state of governance in the institution. The average score was calculated by summing up the rating of the statements for an ideal or practicing state, and dividing the same by the number of the statements of the same class for each respondent. Therefore, the data sheet produced an average score for an ideal state and practicing state of governance for each respondent. The analysis further moved towards computation of the gap between the ideal score and the practicing score. The gap was derived utilising two methods.

\section{Method 1 :}

$\operatorname{GAP}\left(\mathrm{y}_{\mathrm{i}}\right)=\mathrm{a}_{\mathrm{i}}-\mathrm{b}_{\mathrm{i}}$

Method 2 :

$\operatorname{GAP}\left(\mathrm{z}_{i}\right)=\frac{y_{i}}{\left(\mathrm{a}_{i}+\mathrm{b}_{i}\right) / 2}$

[developed by Majumder \& Chakraborty, 2015]

(where $a_{i}$ represents the $i^{\text {th }}$ value of average rating of the responses from the statements referring to practicing governance in the organisation)

$\left(b_{i}\right.$ represents the $i^{\text {th }}$ value of the average rating of the responses from the statements referring to the ideal state of governance in the organisation)

The negative gap projects that the governance practice is lagging behind the ideal state of governance and the positive gap represents that the governance in practice is overriding the ideal state, as per the perception of the faculty members.

The analysis moves forward towards grouping the perception of the faculty members for the practicing state of governance and also removing auto-correlation among variables. Factor Analysis was used as a statistical tool. The factors were named by understanding the nature of grouping. For studying the impact of the factors on the gap derived as per method 1 and method 2, a Regression Analysis was conducted. The initial analysis 
for calculating the mean score of the statements and computing the gap was done by MS Excel and Factor Analysis and Regression output were generated by SPSS version 21.0.

\section{RESULTS AND DISCUSSION}

The dataset passed through reliability test using Cronbach's alpha and the value of $\alpha$ is 0.915 for 57 items, which is more than the prescribed cutoff of 0.70 . Out of the total 127 respondents, approximately, $64 \%$ are male and $34 \%$ are female. Out of the total respondents, $55 \%$ are from Kolkata region, $35 \%$ are from suburban and $10 \%$ are from district management colleges of West Bengal.

The calculation in the analysis shows the mean score of 127 respondents for each statement. Thirty of these statements are regarding identifying the ideal state of governance and 25 are related to the practicing state of governance in the management colleges in West Bengal. Most of the statements enveloping the ideal state of governance practice yield an average rating of 8 (approximately). It indicates that the faculty members strongly agree with most of the statements in support of the ideal state of governance. Similarly, statements focusing on the practicing state of governance yield an average rating between 5 to 6 . Through the responses it is quite evident that faculty members perceive that the elements viz. authority, trust, accountability, discipline etc are practiced in effect but not at the desired level.

The study calculates the gap between the ideal mean score and practicing (or actual) mean score. Most of the gaps measured under both methods show a negative value and thus, it can be said that faculty members think that the ideal state of governance is yet to be achieved in terms of the different elements such as, transparency, accountability, compliance, assessment, research environment, equitable behavior, communication etc. in the organisation. A Correlation Analysis of the gaps corresponding to the two methods was considered and the correlation coefficient value results in 0.984 (p-value $=0.000$ ). Therefore, both gaps under the two methods are positively and highly correlated and hence, any of the derived gaps or both can be used for further analysis. Both forms of these perceptual gaps are commonly named as "Perceived Gap of Practicing Governance" (PGPG).

The study also considered Factor Analysis, taking all the statements in identifying governance in practice. In the Factor Analysis, Kaiser-Meyer-Olkin (KMO) test for measuring sample adequacy is 0.734 or adequate. Hence, the Barlett's test of sphericity is also significant. Therefore, the KMO and Bartlett's Tests both confirm the conduciveness of the sample for Factor Analysis. The Factor Analysis was applied using Principal Component Analysis.

The Factor Analysis results that all the practicing variables are loaded into 6 factors and total variance is explained to the extent of $72.769 \%$. The rotated component matrix is presented in Table 1. The first column of the Table explains statement variables and the second column presents the focal implication of the statements. Further, the individual factor columns are shown where the correlation score of each statement variables with the factors are mentioned. Total of 8 statements identifying ambiance, centralisation, research and development, policies and conduct, student selection process, involvement in decision-making, democratic decision-making process and involvement in education policy-making have been loaded on factor 1 . These variables are more closed to the process and procedures of the organisation. It matches with the "SYSTEM" as explained in the Mckinsey 7s model (Alshaher, 2013) and hence, factor 1 has been named as "SYSTEM". Similarly, factor 2 has been loaded with trust, responsiveness, use of IT in governance, policies and evaluation transparency, academic handling and organisational transparency. This is found to have a close association with Mckinsey 7s model that explained "STYLE" as to how the top managers are managing the company and their interacting process. It can also be stated as the management style of the corporate leaders. Therefore, factor 2 has been named as "STYLE". Under factor 3, variables such as accountability, audit and compliance have been loaded. Both the components are the meeting point on accountability and hence it has been named as "ACCOUNTABILITY". Factor 4 is loaded with role clarity, teamwork, participative decision-making and accessibility of related documents. This factor is more inclined towards the organisational structure and hence, it has been named as "STRUCTURE". Factor 5 loads discipline and equity in the organisation, clearing authority and governing body representation by the faculty members. Hence, it is named as "CULTURE". Factor 6 loads one variable; communication and hence, the name of the factor is "COMMUNICATION".

Further, the study has been extended to gauge the effect of the factors on the "Perceived Gap of Practicing Governance" (PGPG). Regression Analysis has been applied in this connection. In the regression, all the six factors "SYSTEM", "STYLE", "ACCOUNTABILITY", "STRUCTURE", "CULTURE" and "COMMUNICATION" have been considered as predictor variables and the Perceived Gap of Practicing Governance (PGPG) is considered as a dependent variable. 
Table 1: Factor loading and factor naming

\begin{tabular}{|c|c|c|c|c|}
\hline Statements & Notion & $\begin{array}{r}\begin{array}{r}\text { Factor } \\
\text { loading }\end{array} \\
\text { (Correlation } \\
\text { Coefficient) }\end{array}$ & $\begin{array}{r}\text { Factor } \\
\text { No. }\end{array}$ & $\begin{array}{r}\text { Factor } \\
\text { naming }\end{array}$ \\
\hline Organisation motivates for research & Research & 0.744 & Factor 1 & SYSTEM \\
\hline $\begin{array}{l}\text { Staff are satisfied towards the organisational } \\
\text { policy and conducts }\end{array}$ & $\begin{array}{l}\text { Policy and } \\
\text { conduct }\end{array}$ & 0.603 & & \\
\hline $\begin{array}{l}\text { Students of good academic background are } \\
\text { enrolled for studies }\end{array}$ & $\begin{array}{l}\text { Student selection } \\
\text { process }\end{array}$ & 0.569 & & \\
\hline $\begin{array}{l}\text { Faculty representative involves in } \\
\text { decision-making like promotion, tenure and } \\
\text { budgeting etc. }\end{array}$ & $\begin{array}{l}\text { Involvement in } \\
\text { decision-making }\end{array}$ & 0.671 & & \\
\hline $\begin{array}{l}\text { Faculty members can go for the democratic } \\
\text { process for academic decision }\end{array}$ & $\begin{array}{l}\text { Democratic } \\
\text { process }\end{array}$ & 0.425 & & \\
\hline $\begin{array}{l}\text { Educational policies are framed with the } \\
\text { involvement of the faculty members in our } \\
\text { organisation }\end{array}$ & $\begin{array}{l}\text { Involvement in } \\
\text { educated policy- } \\
\text { making }\end{array}$ & 0.634 & & \\
\hline $\begin{array}{l}\text { Students at our campus are widely exposed to } \\
\text { good academic environment }\end{array}$ & Ambiance & 0.619 & & \\
\hline $\begin{array}{l}\text { Decisions are not imposed by the higher } \\
\text { authority instead of taking in democratic way }\end{array}$ & Centralisation & 0.737 & & \\
\hline We have faith in each other in our organisation & Trust & 0.511 & Factor 2 & STYLE \\
\hline $\begin{array}{l}\text { Trustee often meets faculty members for } \\
\text { sharing thought for the betterment of the } \\
\text { institution }\end{array}$ & Responsiveness & 0.512 & & \\
\hline Evaluation process is transparent & $\begin{array}{l}\text { Evaluation } \\
\text { transparency }\end{array}$ & 0.713 & & \\
\hline $\begin{array}{l}\text { We depend more on digital media for } \\
\text { documentation, serving instruction, monitoring } \\
\text { and control etc than manual operation }\end{array}$ & Use of IT & 0.769 & & \\
\hline $\begin{array}{l}\text { Faculty members are very much effective in } \\
\text { the organisation }\end{array}$ & $\begin{array}{l}\text { Academic } \\
\text { handling }\end{array}$ & 0.62 & & \\
\hline Organisation is very transparent in all matters & Transparency & 0.612 & & \\
\hline $\begin{array}{l}\text { Staff are highly accountable to the higher } \\
\text { authority in our organisation }\end{array}$ & Accountability & 0.877 & Factor 3 & ACCOUNTABILITY \\
\hline $\begin{array}{l}\text { Academic review and periodic audit are done } \\
\text { duly }\end{array}$ & Compliance & 0.749 & & \\
\hline $\begin{array}{l}\text { In our organisation, role of each faculty } \\
\text { member is clearly defined for academic } \\
\text { activities }\end{array}$ & Role clarity & 0.824 & Factor 4 & STRUCTURE \\
\hline $\begin{array}{l}\text { Responsibility is not vested on few staff rather } \\
\text { shared among all in our institution }\end{array}$ & Teamwork & 0.523 & & \\
\hline $\begin{array}{l}\text { Faculty members are actively involved in the } \\
\text { management decisions in our college }\end{array}$ & $\begin{array}{l}\text { Participative } \\
\text { decision- } \\
\text { making }\end{array}$ & 0.578 & & \\
\hline Different policies of the organisation concern & Accessibility & 0.513 & & \\
\hline
\end{tabular}

Continued- 
Continued from page 106

\begin{tabular}{|c|c|c|c|c|}
\hline $\begin{array}{l}\text { We are very strict about obeying rule of the } \\
\text { organisation }\end{array}$ & Discipline & 0.555 & Factor 5 & CULTURE \\
\hline $\begin{array}{l}\text { It is observed that competent faculty members } \\
\text { represent the governing body }\end{array}$ & $\begin{array}{l}\text { Governing body } \\
\text { representation }\end{array}$ & 0.749 & & \\
\hline $\begin{array}{l}\text { Authority structure and policy for delegation of } \\
\text { authority is clear to us }\end{array}$ & Authority & 0.556 & & \\
\hline $\begin{array}{l}\text { I perceive that my colleagues treat every } \\
\text { student equally }\end{array}$ & Equity & 0.698 & & \\
\hline $\begin{array}{l}\text { Miscommunication is rare among the staff in } \\
\text { our organisation }\end{array}$ & Communication & 0.759 & Factor 6 & COMMUNICATION \\
\hline
\end{tabular}

Table 2: Regression output: coefficient values

\begin{tabular}{|c|c|c|c|c|}
\hline \multirow[t]{3}{*}{ Model } & \multicolumn{2}{|c|}{ For Method 1} & \multicolumn{2}{|c|}{ For Method 2} \\
\hline & $\begin{array}{r}\text { Unstandardised } \\
\text { coefficients }\end{array}$ & Sig. & $\begin{array}{r}\text { Unstandardised } \\
\text { coefficients }\end{array}$ & Sig. \\
\hline & B & & $\mathrm{B}$ & \\
\hline (Constant) & -2.533 & 0.000 & -0.096 & 0.000 \\
\hline SYSTEM & 0.710 & 0.000 & 0.033 & 0.000 \\
\hline STYLE & 0.709 & 0.000 & 0.031 & 0.000 \\
\hline ACCOUNTABILITY & 0.587 & 0.000 & 0.025 & 0.000 \\
\hline STRUCTURE & 0.766 & 0.000 & 0.034 & 0.000 \\
\hline CULTURE & 0.574 & 0.000 & 0.025 & 0.000 \\
\hline COMMUNICATION & 0.209 & 0.003 & 0.009 & 0.000 \\
\hline
\end{tabular}

The Regression Analysis results $\mathrm{R}^{2}$ value as 0.793 that signifies the model is strong and predictor variables are able to explain dependent variable to the extent of $79 \%$ (approximately). In other words, it can be stated that factors of practicing governance derived from Factor Analysis are able to explain the Perceived Gap of Practicing Governance to the extent of $79 \%$. Besides, the model is significant as the p-value $(0.000)$ is $<0.05$ (as per regression output).

Table 2 projects the factors' impact on the Perceived Gap of Practicing Governance which is measured under method 1 and method 2, respectively. Unstandardised coefficient value (B) and $\mathrm{p}$ or significance value can be understood from the Table 2. Here, factor unstandardised coefficients (B) are positive and hence, it can be expressed that a positive impact of the factors exist on the perceived gap derived under method 1 . The $p$-value of all the factors are showing less than 0.05 and therefore, can be said that all the factors; SYSTEM, STYLE, ACCOUNTABILITY, STRUCTURE, CULTURE and COMMUNICATION, have a significant impact on the Perceived Gap of Practicing Governance (PGPG). The regression equation can be written as follows :

Perceived Gap of Practicing Governance (PGPG) =

0.710 (System) +0.709 (Style) +0.587 (Accountability) +

0.766 (Structure)+ 0.574 (Culture)+

0.209 (Communication)- 2.523

[Dependent Variable: Perceived Gap of Practicing Governance]

Similarly, the perceived gap derived under method 2 has also been regressed with the different factors of governance practices. 
The model summary results show that the $\mathrm{R}^{2}$ value is 0.894 (as per SPSS output) i.e. the predictor variables are able to explain around $89 \%$ of the model. On the other hand, the factor of practicing governance is able to explain PGPG to the extent of $89 \%$. The model is also highly significant as the p-value $(0.000)$ is less than 0.05 .

Table 2 showing the coefficient values depicts that factors of practicing governance exert a significant influence on the PGPG derived under method 2. For all factors, the p-value is less than 0.05 (as per Table 2). Therefore, a similar conclusion can be drawn that SYSTEM, STYLE, ACCOUNTABILITY, STRUCTURE, CULTURE, and COMMUNICATION are major concerns for the practicing governance gap. As done earlier, the regression equation can be drawn as follows:

Perceived Gap of Practicing Governance $(\mathrm{PGPG})=$ $0.033($ System $)+0.031($ Style $)+0.025($ Accountability $)+$

$0.034($ Structure $)+0.025$ (Culture) +

0.009 (Communication)- 0.096

With the help of Central Tendency and Regression Analysis, the paper brings forth an understanding of the present scenario of governance practices in different management colleges affiliated under the Maulana Abul Kalam Azad University of Technology, West Bengal. The research results made it clear that there is a gap in governance practices as per the perception of faculty members. College environment, policy-making, decision-making process, student admission procedure etc named "SYSTEM" has a strong impact on practicing governance. From the analysis, it can also be said that transparency can bring trust to the stakeholders and that IT enables a system to ensure transparency. A transparent environment becomes more responsive to the stakeholders since good governance ensures the transparent environment. Therefore, in general, it can be indicated that the management colleges are lagging behind in these practices. The study has also revealed that accountability and compliance mechanism being practiced in the colleges cannot be considered as upto the desired level to meet the stakeholders' expectations. The "STRUCTURE", in terms of role clarity, teamwork and participative decision-making in these organisations does not exist up to the level of satisfaction of the employees. Teamwork and decision-making affect the role clarity in the system. Governance fails to optimise itself due to this structural deficiency. Organisational culture backed by the discipline, equity approach, leadership style etc and communication, which contributes with a positive role to the governance practices, have also been observed to be in crisis in meeting the present demand of the faculty members for achieving a state of good governance.

\section{CONCLUSION}

Good governance has become a major issue and challenge in the higher education sector, not only in India but also globally. In higher education, the Management programmes occupy a significant position. Such programmes create corporate leaders and management colleges act as processing units. Good governance in the colleges controls the system as a whole and add quality in creation. Good governance can be practiced with the presence and proper implementation of different elements studied in the paper. The ideal state of governance is a theoretical concept only, but tending towards the ideal will give a clean indication for better governance practices. The study has made a clear indication towards the lack of practice of good governance by the private management colleges in West Bengal. The study provides a suggestion towards the path as to how a management institute vis-à-vis any other education institute can create a better environment for practicing good governance in the organisation. The faculty fraternity of West Bengal perceives that the management colleges can develop their governance practices by adopting a proper system of workflow, changing "structural pattern", "management style" and developing good culture in the organisation. Besides, an imposition of proper accountability along with sound communication systems is recommended for these colleges for achieving good governance practice.

The present research study has considered the perception of teaching fraternity. Further research can be extended to the perceptions of other stakeholders of management colleges towards good governance practice. It also opens up the dimension for studying the governance practices in government or governmentaided management colleges.

\section{REFERENCES}

Alhaji, I. A. and Yusoff, W. B. F. W. (2012) An empirical study of the role of audit committee in promoting good corporate governance, $3^{r d}$ International Conference on Business and Economic Research Proceeding, Bandung, Indonesia, pp: 165177 [Online] Available from: http://eprints.uthm.edu.my/2513/ [Accessed: $1^{\text {st }}$ of May 2017].

Alshaher, Ali Abdul-Fattah (2013) The Mckinsey 7s model framework for e-learning system readiness assessment, International Journal of Advances in Engineering \& Technology, 6(5), pp: 1948-1966 [Online] Available from: https://www.researchgate.net/publication/321918535_THE_ MCKINSEY_7S_MODEL_FRAMEWORK_FOR_ELEARNING_SYSTEM_READINESS_ASSESSMENT [Accessed: $5^{\text {th }}$ October 2017].

DOI: https://doi.org/10.4018/978-1-4666-2464-1.ch009 
Aloj, E., De Castro, M. and Zollo, A. (2007) Higher education in environmental and ethical-social communication for companies: new challenges and new perspectives for the scientific community, In Filho, W. L. (ed.) Higher Education and the Challenge of Sustainability: Problems, Promises and Good Practice, Greece: Environmental Education Center of Soufli, pp: 1-7 [Online] Available from: http://citeseerx.ist.psu.edu/ viewdoc/download [Accessed: 22 ${ }^{\text {nd }}$ June 2017].

Asare, K. B. and Adzrolo, B. (2013) Lecturers', students' and administrators' perception of discipline in the Faculty of Education, University of Cape Coast, Ghana, Sage Open, pp: 1-8 [Online] Available from: https://journals.sagepub.com/doi/ full/10.1177/2158244013494208 [Accessed: $25^{\text {th }}$ March 2017].

DOI: https://doi.org/10.1177/2158244013494208

Brusoni, M., Damian, R., Sauri, J. G., Jackson, S., Kömürcügil, H., Malmedy, M., Matveeva, O., Motova, G., Pisarz, S., Pol, P., Rostlund, A., Soboleva, E., Tavares, O. and Zobel, L. (2014) The concept of excellence in higher education, Occasional $\mathrm{Pa}$ pers, 20, Brussels, Belgium: European Association for Quality Assurance in Higher Education, pp: 9-14 [Online] Available from: https://enqa.eu/indirme/papers-and-reports/occasional-papers/ENQA\%20Excellence\%20WG\%20Report_The $\% 20$ Concept $\% 20$ of $\% 20$ Excellence $\% 20$ in $\% 20$ Higher $\% 20$ Education.pdf [Accessed: 12 ${ }^{\text {th }}$ August 2017].

DOI: https://doi.org/10.1080/13538320902995741

Chahal, M. (2015) Higher education in India: emerging issues, challenges and suggestions, International Journal of Business, Quantitative Economics, and Applied Management Research, 1(11) [Online] Available from: http://ijbemr.com/wp-content/ uploads/2015/05/Higher_Education_in_India_Emerging_Issues_Challenges_and_Suggestions.pdf [Accessed: $10^{\text {th }}$ June 2017].

DOI: https://doi.org/10.15242/icehm.ed0115098

Chitumbo, M. M. E. and Kakana, F. (2011) Promoting good governance through freedom of access to information and censorship to information, pp: 185-191 [Online] Available from: http://dspace.unza.zm:8080/xmlui/bitstream/handle/123456789/190/miyanda0001.PDF?sequence $=1 \quad$ [Accessed: $11^{\text {th }}$ July 2017].

Dayanandan, R. (2013) Good governance practice for better performance of community organizations - myths and realities, Journal of Power, Politics \& Governance, 1(11) [Online] Available from:http://jppgnet.com/journals/jppg/Vol_1_No_1_ December_2013/2.pdf [ Accessed: $9^{\text {th }}$ July 2017].

de Lourdes Machado-Taylor, M. (2011) Complex adaptive systems: a trans-cultural undercurrent obstructing change in higher education, International Journal of Vocational and Technical Education, 3(2), pp: 9-19 [Online] Available from: https:// www.researchgate.net/publication/262450911_Complex_ adaptive_aystems_A_trans-cultural_undercurrent_obstructing_change_in_higher_education [Accessed: $12^{\text {th }}$ July 2017].

De Silva Loku Waduge, C. S. and Armstrong, A. (2011) Assessment of good governance in the Australian university sector, 25th Annual Australian and New Zealand Academy of Management (ANZAM) Conference, pp: 1-15 [Online] Available from: https://www.anzam.org/wp-content/ uploads/2018/03/517_ANZAM2011-231.pdf [Accessed: $1^{\text {st }}$ August 2017].

Duncan, R. C. (2003) Governance and growth, Symposium on Governance, Suva, Fiji: University of the South Pacific.

Franzoni, S. and Gennari, F. (2013) School governance: an international comparison, US-China Education Review B, 3(10), pp: 772-779 [Online] Available from: https://www.researchgate.net/publication/278031482_School_Governance An_International_Comparison [Accessed: $1^{\text {st }}$ August 2017]. DOI: https://doi.org/10.17265/2161-6248/2013.10B.004

Hawawini, G. (2005) The future of business schools, Journal of Management Development, 24(9), pp: 770-782 [Online] Available from: https://www.researchgate.net/publication/235274512_The_future_of_business_schools [Accessed: $2^{\text {nd }}$ August 2017].

DOI: https://doi.org/10.1108/02621710510621286

India, All India Council for Technical Education (2017) List of AICTE approved Institutes in 'Management' ' $P G$ ' 'Unaided Private for the state West Bengal for the academic year: 2015 2016 [Online] Available from: https://www.facilities.aicte-india.org/dashboard/pages/angulardashboard.php\#!/approved [Accessed: $1^{\text {st }}$ August 2017].

DOI: https://doi.org/10.1007/978-1-349-94186-5_35

India, Maulana Abul Kalam Azad University of Technology, West Bengal (2017) List of Affiliated Colleges Under Maulana Abul Kalam Azad University of Technology, West Bengal [Online] Available from: http://www.wbut.ac.in/big_files/College\%20list-2015-16-as\%20on\%2022-09-2015.pdf [Accessed: $1^{\text {st }}$ August 2017].

India, Ministry of Human Resource Development (2016) University and Higher Education [Online] Available from: http:// mhrd.gov.in/university-and-higher-education [Accessed: $1^{\text {st }}$ July 2017].

India, National Knowledge Commission (2006) National Knowledge Commission: Report to the Nation 2006, Government of India, pp: 56-58 [Online] Available from: http:// kshec.ac.in/perspectives/NKC $\% 20$ Report $\% 20$ to $\% 20$ the $\% 20$ Nation\%202006.pdf [Accessed: 10 ${ }^{\text {th }}$ August 2017].

International Fund for Agricultural Development (1999) Good Governance: An Overview, pp: 1-10 [Online] Available from: https://www.ipa.government.bg/sites/default/files/pregled-dobro_upravlenie.pdf [Accessed: $5^{\text {th }}$ April 2017].

Jesiah, S. (2010) Response of higher education to globalisation: empirical evidences from India, Journal of Social and Economic Development, 12(2) [Online] Available from: https://s3.amazonaws.com/academia.edu.documents/32182655/JSED2010. pdf?response-content-disposition=inline $\% 3 \mathrm{~B} \% 20$ file- 
name\%3DResponse of HIgher Education to Globalis.pd$\mathrm{f} \& \mathrm{X}$-Amz-Algorithm=AWS4-HMAC-SHA256\&X-Amz-Credential=AKIAIWOWYYGZ2Y53UL3A\%2F20191108\%2Fus-east-1\%2Fs3\%2Faws4_request\&X-Amz-Date $=2019$ $1108 \mathrm{~T} 104137 \mathrm{Z} \& \mathrm{X}-\mathrm{Amz}$-Expires $=3600 \& \mathrm{X}-\mathrm{Amz}-$ SignedHeaders $=$ host $\& X-A m z-$ Signature $=6$ dab0c7bbcec $69 \mathrm{c} 071 \mathrm{~b} 7 \mathrm{e}-$ f7a176119f8a58c4a5f457ce36c275b64605c2c91c8 [Accessed: $6^{\text {th }}$ August 2017].

DOI: https://doi.org/10.1002/dama.201690051

Kidwell, J. J., Vander Linde, K. M. and Johnson, S. L. (2000) Applying corporate knowledge management practices in higher education, Educause Quarterly, 23(4), pp: 28-33 [Online] Available from: https://er.educause.edu/ /media/files/articles/2000/12/eqm0044.pdf?la=en [Accessed: $8^{\text {th }}$ August 2017].

Leach, W. D. (2008) Shared governance in higher education: structural and cultural responses to a changing national climate, Sacramento: California State University, pp: 3-21 [Online] Available from: https://pdfs.semanticscholar.org/dfac/92e32ef98ba211c0dfc8790bfd5c49c32e16.pdf?_ga=2.184347630.912114274.1564752961250325660.1564752961 [Accessed: $12^{\text {th }}$ July 2017].

DOI: https://doi.org/10.2139/ssrn.1520702

Lewis, M. and Pettersson, G. G. (2009) Governance in education: raising performance in the sector--overview of issues and evidence [Online] Available from: http://siteresources.worldbank. org/EXTHDOFFICE/Resources/5485726-1239047988859/ GAC_in_education_master_12_April_2009.pdf [Accessed: $20^{\text {th }}$ August 2017].

DOI: http://dx.doi.org/10.2139/ssrn.1992404

Majumdar, A. and Chakraborty, R. (2015) Measurement of efficiency of hospital care in terms of patients' health expenses, TSM Business Review, 3(1), pp: 41-53, Madurai, India: Thiagarajar School of Management [Online] Available from: http://tsm.ac.in/wp-content/uploads/2019/08/TBR_June2015. pdf\#page $=51$ [Accessed: $12^{\text {th }}$ July 2017].

Malesela, L. J. (2016) The role of monitoring and evaluation to enhance good governance in the department of higher education and training, Master of Public Administration, University of Pretoria [Online] Available from: https://www. academia.edu/30212295/THE_ROLE_OF_MONITORING_ AND_EVALUATION_TO_ENHANCE_GOOD_GOVERNANCE_IN_THE_DEPARTMENT_OF_HIGHER_EDUCATION_AND_TRAINING [Accessed: $12^{\text {th }}$ July 2017].

Martirosyan, N. M., Saxon, D. P. and Wanjohi, R. (2014) Student satisfaction and academic performance in Armenian higher education, American International Journal of Contemporary Research, 4(3) [Online] Available from: http://www.aijcrnet. com/journals/Vol_4_No_2_February_2014/1.pdf [Accessed: $30^{\text {th }}$ July 2017].

Meyer, M., Bushney, M. and Ukpere, W. (2011) The impact of globalisation on higher education: achieving a balance between local and global needs and realities, African Journal of Business Management, 5(15), pp: 6569-6578 [Online] Available from: https://academicjournals.org/journal/AJBM/article-abstract/E488B3E14863 [Accessed $4^{\text {th }}$ April 2017].

DOI; https://doi.org/10.5897/AJBM11.205

Migliore, Laura-Ann (2012) Leadership, governance and perceptions of trust in the higher education industry, Journal of Leadership Studies, 5(4) [Online] Available from: https://onlinelibrary.wiley.com/doi/pdf/10.1002/jls.20241] [Accessed: $12^{\text {th }}$ April 2017].

DOI: https://doi.org/10.1002/jls.20241

Modi, S. (2014) Higher education in India: issues and challenges, Academe, XVII(1), pp: 15-20 [Online] Available from: http://hrdcshimla.org/Academe_2014/3.pdf [Accessed: $5^{\text {th }}$ July 2017].

Mutsotso, S. N. and Abenga, E. S. B. (2010) Study methods for improving quality learning and performance in higher education, Educational Research and Review, 5(12), pp: 808-813 [Online] Available from: https://academicjournals.org/journal/ ERR/article-full-text-pdf/723D2174219 [Accessed: $30^{\text {th }}$ July 2017].

Nestor, S. and Jesover, F. (2000) OECD principles of corporate governance on shareholder rights and equitable treatment: their relevance to the Russian federation [Online] Available from: https://www.imf.org/external/pubs/ft/seminar/2000/invest/pdf/ nestor.pdf [ Accessed: 28 ${ }^{\text {th }}$ July 2017].

Okwechime, C. (2015) Interfacing effective communication, good governance and sustainable development in Nigeria, GSTF Journal on Media \& Communications, 2(2), pp: 27-37 [Online] Available from: https://pdfs.semanticscholar. org/aace/41274dfd0f2df871958b51d8f81f8ce7d0a6.pdf [Accessed: $2^{\text {nd }}$ August 2017].

Othman, Z. and Rahman, R. A. (2014) Attributes of ethical leadership in leading good governance, International Journal of Business and Society, 15(2), pp: 359-372 [Online] Available from: http://www.ijbs.unimas.my/repository/pdf/Vol15-no2paper10.pdf [Accessed: 2 ${ }^{\text {nd }}$ August 2017].

Rasian, Z. (2009) Higher education governance in developing countries, challenges and recommendations: Iran as a case study, Nonpartisan Education Review/Essays, 5(3), pp: 1-18 [Online] Available from: https://nonpartisaneducation.org/Review/Essays/v5n3.pdf [Accessed: $4^{\text {th }}$ August 2017].

Ravindran D. and Sudharani. K. M. (2012) Students' expectation, perception and satisfaction towards the management educational institutions, Procedia Economics and Finance, 2, pp: 401-410 [Online] Available from: https://reader.elsevier.com/reader/sd/ pii/S2212567112001025?token $=$ D882CA5B97370B3D856EAB0F1B07299367464BEA1F84C4CD2D8994029AE52CF380949886DC672693E1776EE3909ED9FA [Accessed: $5^{\text {th }}$ August 2017].

DOI: https://doi.org/10.1016/s2212-5671(12)00102-5 
Sahay, B. S. and Thakur, R. R. (2007) Excellence though accreditation in Indian b-school, Global Journal of Flexible Systems Management, 8(4), pp: 9-16 [Online] Available from: https://link.springer.com/article/10.1007/BF03396529 [Accessed: $3^{\text {rd }}$ August 2017].

DOI: https://doi.org/10.1007/BF03396529

Sapru, R. K. and Sapru, Y. (2014) Good governance through e-governance with special reference to India, Indian Journal of Public Administration, 60(2), pp: 313-331 [Online] Available from: http://iipa.org.in/New\%20Folder/8--Sapru.pdf [Accessed: $4^{\text {th }}$ August 2017].

DOI: https://doi.org/10.1177/0019556120140208

Schwartzman, S. (2001) Higher education reform: Indonesia and Latin America [Online] Available from: http://www. schwartzman.org.br/simon/jakarta.htm [Accessed: $7^{\text {th }}$ August 2017].

Shrivastava, S. K. (2006) Higher education system in India: challenges \& strategies for reforms, In: Washington Symposium, National Association of International Educators (NAFSA), 28.

Singh, V., Grover, S. and Kumar, A. (2008) Evaluation of quality in an educational institute: a quality function deployment approach, Educational Research and Review, 3(4), pp: 162-168 [Online] Available from: https://www.researchgate.net/profile/ Vikram_Singh35/publication/237262613_Evaluation_of_quality_in_an_educational_institute_a quality function_deployment_approach/links/56e41b2008ae65dd4cbe7755.pdf [Accessed: $4^{\text {th }}$ April 2017].

Srivastava, M. (2009) Good governance- concept, meaning and features: a detailed study [Online] Available from: https://ssrn. com/abstract $=1528449$ [Accessed: $2^{\text {nd }}$ April 2017].

DOI: https://doi.org/10.2139/ssrn.1528449

Tettey-Enyo, A. (1995) School discipline, CHASS Journal: The Educator, 1, pp: 33-36.

Thanuskodi, S. (2011) Higher education in India: challenges and opportunities, International Journal of Science and
Technology Education Research, 2(6), pp: 106-108 [Online] Available from: https://academicjournals.org/journal/IJSTER/ article-full-text-pdf/E28A63A3187 [Accessed: $5^{\text {th }}$ April 2017].

Umar, Z. (2016) Defining Governance [Online] Available from: http://mo.ibrahim.foundation/news/2016/defining-governance/ [Accessed: $9^{\text {th }}$ August 2017].

United Nations Economic and Social Commission for Asia and the Pacific (2009) What is Good Governance? [Online] Available from: www.unescap.org/sites/default/files/good-governance.pdf [Accessed: $5^{\text {th }}$ February 2017].

US Agency for International Development (USAID) (2003) Approaching education from a good governance perspective, USAID Resource Guide for Joint DG/Education Programs, Washington DC: US Agency for International Development [Online] Available from: http://pdf.usaid.gov/pdf_docs/Pnacr222.pdf [Accessed: $9^{\text {th }}$ August 2017].

Yallaprgada, V. R. Naga Pawan and Vitukuru, S. (2012) Private higher education institutions and e-governance, Journal of E-Governance, 35(4), pp: 405-407 [Online] Available from: http://content.iospress.com/articles/journal-of-e-governance/ gov00321 [Accessed: $4^{\text {th }}$ April 2017].

DOI: https://doi.org/10.3233/GOV-2012-0321

Yash Pal Committee (2009) Report of the Committee to Advise on 'Renovation and Rejuvenation of Higher Education' (Prof. Yashpal Committee Report), pp: 32-35 [Online] Available from: https://mhrd.gov.in/report-committee-advise-renovation-and-rejuvenation-higher-education-prof-yashpal-committee-report [Accessed: $10^{\text {th }}$ August 2017].

Zaman, K. (2015) Quality guidelines for good governance in higher education across the globe, Pacific Science Review B: Humanities and Social Sciences, 1(1), pp: 1-7 [Online] Available from: https://reader.elsevier.com/ reader/sd/pii/S2405883116000022?token $=300 \mathrm{~A} 3089 \mathrm{DA}-$ 496FA 4E 2 A D 71 DF 6D 12 A C 6B 8F 275 CEBCFB 1 F 3539CB20865FD7FD8D29C66CF08B2590604B8548BBE0A83F26F [Accessed: $4^{\text {th }}$ April 2017].

DOI: https://doi.org/10.1016/j.psrb.2016.01.001 